\title{
The activity of alcoholic extract of Garlic on the growth of Staphylococcus aureus with estimation of median lethal dose in lab. Mice
}

\author{
E. M. Rashid \\ Med. Tech. Institute / \\ Mansour \\ Foundation of Tech. Edu.
}

\author{
Sh. Jamal \\ Coll of Med./ Univ. of \\ Baghdad
}

\author{
Sh. M. Al-khazraji \\ Med. Tech. Institute / \\ Mansour \\ Foundation of Tech. Edu.
}

\begin{abstract}
The study was intended to investigate the in vitro activity of alcoholic extract of Garlic on the inhibition of growth of Staph. aureus which was isolated from skin infections, and determine the median lethal dose ( LD 50 ) of the extract in lab. mice. The Garlic was extracted by ethyl alcohol $95 \%$, the ratio of ethanolic extraction amounted $44 \%$ of the weight of dry substance. Graduated concentration were prepared from alcoholic extract of Garlic from 10$100 \mathrm{mg} / \mathrm{ml}$. Their activities were checked up against Staph.aureus by agar diffusion method using ethylene glycol as control. The results showed that the sensitivity of the test bacteria was gradually increased with increasing the extract concentration, the concentration 10-30 $\mathrm{mg} / \mathrm{ml}$ were rather low active in preventing the growing of Staph. aureus in culturing media, the concentrations $40-70 \mathrm{mg} / \mathrm{ml}$ were moderately active ,meanwhile the concentrations 80-100 $\mathrm{mg} / \mathrm{ml}$ were highly active against the growing of Staph.aureus. The results also showed that the LD50 of the ethanolic extract of Garlic when it is orally administered to the lab mice by gradual concentrations was about $8000 \mathrm{mg} / \mathrm{kg}$ body weight. The toxic signs during $24 \mathrm{hrs}$ after initial feeding with the extract were rapid breathing followed by dullness, then death .

\section{Introduction}

Many plant-derived substances touted to improve health are sold around the world, Garlic (Allium sativum ) is believed by many people to be useful for diseases prevention. The Garlic belongs to the Family "Liliaceae", and the important components are : volatile oils that contain diallyl disulfate, alliin and allicin with allinase and many vitamins (Hussein 1986). In ancient Egypt, Garlic was given to laborers and soldiers to mitigate fatigue or to prevent recovery from physical exhaustion (Essman et al 1984 ). Louis Pasteur was the first to describe the anti- bacterial effect of Garlic juice and found that it exhibit a broad antibacterial spectrum against both Grampositive and Gram-negative bacteria (Sivam et al 2001 ). Garlic also long been known

al 2005). Researches have been recently focused on the prevention and curative effects of Garlic on cancer (Black et al 1994), cardiovascular disease ( Jacob et al 1993), and skin disease (كنة ايناس 2003) (كريم). The purposes of this study are to detect the in vitro activity of Garlic extract in the growth inhibition of Stapyllococcus aureus isolated from skin diseases, so this study carried out to :-

1-Prepare alcoholic extraction of Garlic in ethyl alcohol $95 \%$.

2-Detection of inhibitory effects of different concentrations of extract on the growth of Staph. aureus by using agar well diffusion method .

3- Determination of median lethal dose ( LD 50 ) of extract in lab. mice .
\end{abstract} to have anti-fungal, anti-protozoal, antiviral, and anti-bacterial properties (Bakri et 


\section{Materials and Methods}

Materials :-

1-Culture media :

Are prepared according to the producing companies instructions and sterilized in autoclave at $121 \mathrm{C}$ under pressure of 15 pounds/ inche after incubation at $37 \mathrm{C}$ for $24 \mathrm{hrs}$, used for culture and diagnosis of bacteria used in this study .

2- Chemicals and reagents :

Specific chemicals and reagents are used for biochemical tests to confirmed the diagnosis of bacteria ( Forbes et al ).

3- Equipments :

Different equipments were used such as:- analytical balance, autoclave, incubator, microscope, sensitive balance, spectrophotometer, and blender.

Methods :1-Preparation of plant :

Garlic were collected from the local market and authenticated as Allium sativum (University of Baghdad Herb Centre ) .

2-Extraction methods :

Garlic was skinned and sliced, 50 gm sliced Garlic were crushed in awarding blender for 1 minute, then soaked in $450 \mathrm{ml}$ ethanol $95 \%$. It was naturally extracted for 3 months at room temperature, the mixture was separated in test tubes by centrifugation $3000 \mathrm{rpm}$, the filtrate was dried in oven 37 $\mathrm{C}$ for $24 \mathrm{hrs}$. The final product was stored in freezer at-20 C (Krell et al 1996).

3-Culture preparation:

The bacteria were activated by re culturing on nutrient agar and kept in the incubator for $24 \mathrm{hrs}$ at $37 \mathrm{C}$, then transferred in to sterilized tubes containing heart infusion broth , then placed in the incubator for 24-72 hrs at $37 \mathrm{C}$. Total bacterial count was estimated by using spectrophotometer, the percentages of light transmittance was $26 \%$ at a wave length of 580 nanometer, while the light transmittance was $100 \%$ for nutrient broth used to prepare the bacteria (Jassim 2003).

4-Preparaton of standard dilutions of Garlic extract :

The dilution were prepared by using ethylene glycol which is inert solvent against microorganism (Charlas et al 1969 ), and by using serial concentrations from $10-100$ $\mathrm{mg}$ from the extract, then dilute it with ethylene glycol and the volume was completed to $2 \mathrm{ml}$ to get the final concentrations from 1-10\%.

5 -Garlic extract activity test "well diffusion method ":

Screening of the anti-bacterial activity was performed by well diffusion technique (Saeed et al 2005 ). The MuellerHinton agar plates were seeded with $0.1 \mathrm{ml}$ of the standardized inoculums of the bacteria. The inoculums was spread evenly over plate with sterile glass spreader. The seeded plates were allowed to dry in the incubator at $37 \mathrm{C}$ for 20 minutes. A standard crak border of $8 \mathrm{~mm}$ diameter was used to cut uniform wells on the surface of the plates , and $0.1 \mathrm{ml}$ of each concentration was introduced in the well with ethylene glycol as a control. The inoculated plates were incubated at $37 \mathrm{C}$ for $24 \mathrm{hrs}$ and zone of inhibition diameter was measured to the nearest millimeter $(\mathrm{mm})$.

6-Determination of LD50 of Garlic extract:

Thirty - six albino mice 6 weeks age weighing 20-25 g were classified into 6 groups, the first five groups were orally administered by gradual doses of Garlic extract $(1000,3000,5000,7000$, and 9000 $\mathrm{mg} / \mathrm{kg}$ body weight ) respectively. The sixth group was orally administered by ethylene glycol as a control group (the dose volume was $0.4 \mathrm{ml} / 20 \mathrm{~g}$ body weight ). The toxic signs and mortality rate were observed within $24 \mathrm{hrs}$ after extract administration ( Dixon et al 1980 ). 


\section{Results}

1-Identification of bacteria :

a-The bacteria grow well on mannitol salt agar .

b- Microscopic examination:- Grampositive, spherical in shape .

c- Biochemical tests were confirmed the identification of Staph. aureus, catalase and gelatinase + ve, oxidase - ve, blood agar (Bhaemolysis, and production of local golden pigment ).

2- The inhibitory effect of Garlic extract :

The sensitivity of the previously mentioned bacteria gradually increased with the increment of concentration of extract . The zone of the inhibition was $8.2+0.2 \mathrm{~mm}$ was recorded for the concentration of 10 $\mathrm{mg} / \mathrm{ml}$, and $19.6+0.5 \mathrm{~mm}$ was for the concentration $100 \mathrm{mg} / \mathrm{ml}$. The concentrations $10-30 \mathrm{mg} / \mathrm{ml}$ were rather low active in preventing the growth of Staph. aureus, the concentrations $40-70 \mathrm{mg} / \mathrm{ml}$

Table (1) The in vitro inhibitory effect of different concentrations of garlic extract on the growth of Staph. aureus measured by the diameter of zone of inhibition ( $\mathrm{mm}$ ) .

\begin{tabular}{|c|c|c|c|c|}
\hline Concentrations (mg/ml) & \multicolumn{3}{|c|}{ Diameters of inhibition zone ( mm ) } & Mean + SE \\
\hline & & & & \\
10 & 8 & 8.2 & 8.4 & $8.2+0.3$ \\
20 & 8.8 & 9.4 & 9.4 & $9.3+0.2$ \\
30 & 9.8 & 10.2 & 10.3 & $10.1+0.2$ \\
40 & 12.2 & 12.2 & 12.5 & $12.3+0.1$ \\
50 & 12.8 & 13 & 13.5 & $13.1+0.3$ \\
60 & 14.8 & 15 & 15.2 & $15+0.2$ \\
70 & 16.4 & 17.2 & 16.8 & $16.8+0.3$ \\
80 & 18.6 & 18.8 & 18.7 & $18.7+0.1$ \\
90 & 18.8 & 19.5 & 19.6 & $19.3+0.3$ \\
100 & 19.2 & 19.7 & 19.9 & $19.6+0.2$ \\
& & & &
\end{tabular}




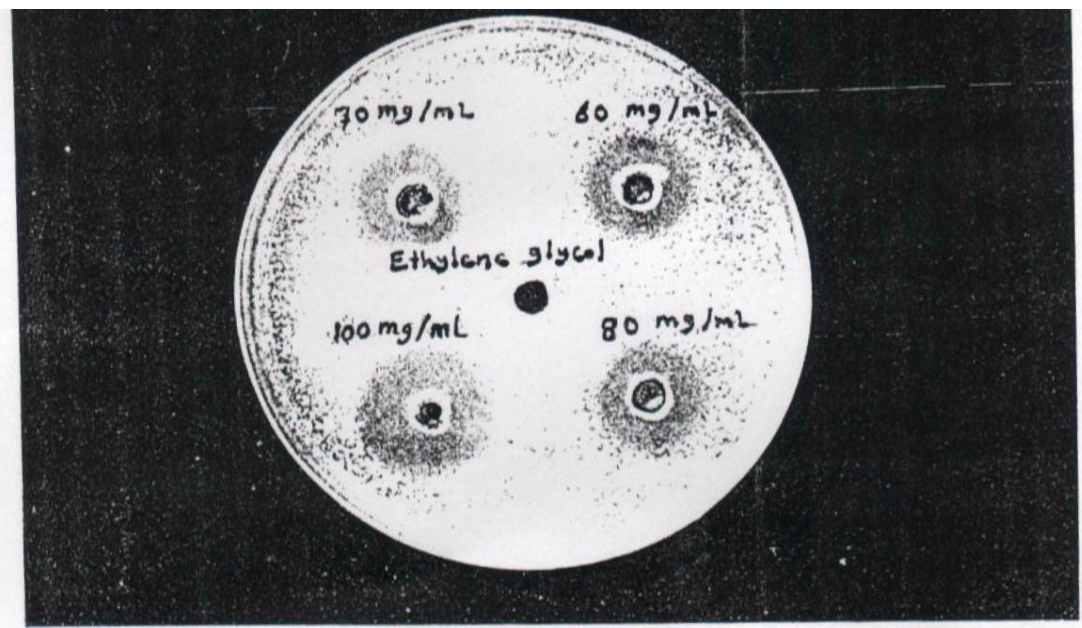

Figure(1):The inhibitory effect of different concentrations of Garlic extract on the growth of Staph.aureus.

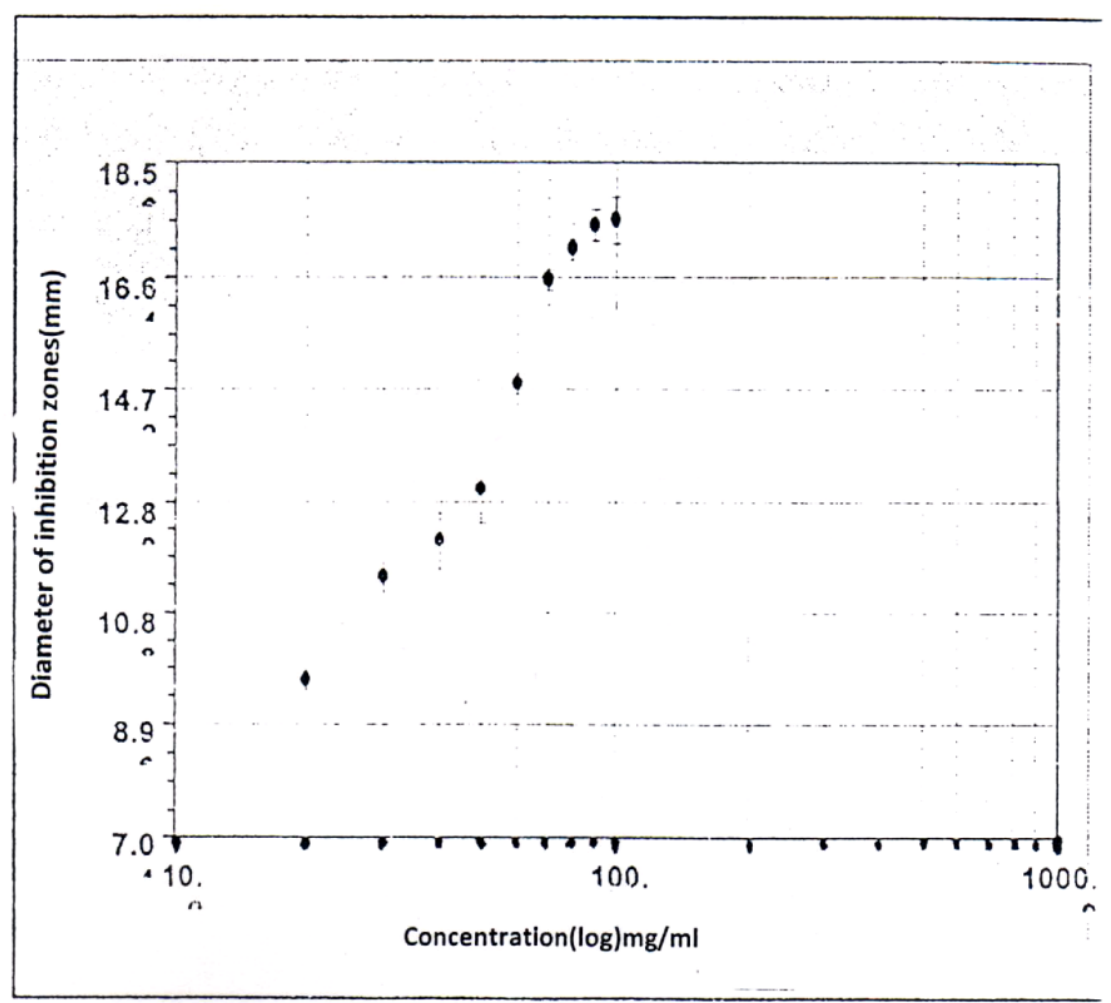

Figure(2):The relationship between the concentrations of garlic extract and the diameter of inhibition zones in the growth of Staph.aureus. 


\section{Discussion}

In this study, Garlic possessed antibacterial effect against Staph. aureus, and the sensitivity of the bacteria was gradually increased with the increasing of extract concentrations (Table 1) Bacterial drug resistance is a world problem, a high number of bacterial species have become resistant to anti-bacterial drugs( Garau et al 1994 ). Thus, there is a need to evaluate the efficacy of plant chemicals concerning with the growth of bacteria by extracts of plants to be used, with dichloromethane extraction ( Laenger et al 1996 ), maceration and soxhlet fluid extraction with hexane (Vilegs et al 1997 ). These preparations are unavailable to person for self medication , with these consideration the activity of Garlic extract on the growth of Staph. aureus were studied .Garlic has been known to have anti-bacterial, anti-fungal, and antiviral activity (Bakri et al 2005). The present results are in fair correlation with the study above and the study carried out by Reuter $\underline{e t} \underline{a l} 1996$ in which Garlic has been reported to inhibit the growth of Staphylococcus and many other species. In another study crude juice of Garlic has been found to be high active against $E$. coli and Salmonella typhi (Abdon et al 1972 ). Sasaki $\underline{\text { t }}$ al 1999 found the Garlic activity against methicillin-resistant Staph. aureus and candida albicans .Garlic extract possesses anti-bacterial activity against H.pylori at moderate concentration, thus it has protective effect against stomach ulcer (Satiawane $\underline{e t} \underline{a l} 2005$ ). this observation needs many studies and investigations .Allicin is biologically active compound responsible for the anti-microbial properties of Garlic. The inhibitory effect of Garlic on the growth of Staph. aureus in this study is due to the important allicin compound in the Garlic extract . Pure allicin was effective against many clinical isolates of Aspergillus in vitro study ( Shadkchan et al 2004). Further studies are clearly required to investigate the Garlic extract effects on fungi, yeasts, and mycoplasma species . The study also showed that the LD50 of Garlic extract was about $8000 \mathrm{mg} / \mathrm{kg}$ body weight, and this is considered that the extract is very safe when taken orally . There were no previous toxicological studies that focused on the LD50 of Garlic extract for comparison. The determination of LD50 may differs in its value among other studies which were achieved, this is due to the differences in Garlic sources and consequently differences in the chemical composition, the differences in lab. animals used, their species and numbers, the method of LD50 calculation and other circumstances that related to the researchers.

\section{References}

1. Abdou A, Abou-Zaid AA, AlSherneeny MR , \& Abou-AlGheat ZH , Anti-microbial activities of Allium sayivum, Allium cepa , Rephanus sayivus , Capsicum frutescens , Eruca sativa and Allium kurret on bacteria “, Plant foods for Humen Nutrition , 1972;22:29-35.

2. Bakri IM, \& Douglas CW., Inhibitory effect of garlic extract on oral bacteria , Arch. Oral Biol. , , 2005 ; 50:645-651.
3. Black E., Flavorants from Garlic, onion and other alliums and their cancerprevention property, $A C S$ synp.Ser., , 1994 ; 546: 84 -96.

4. Charles OW, Ole G, \& Robert FD , Textbook of organic medicinal and pharmaceutical chemistry, 5 th. Edition , J.B. Lippincott company, Philadelphia and Toronto, 1969 .

5. Dixion WJ Efficient 463. analysis of experimental observation, Ann. Rev. Pharmacol. Toxicol. , 1980; 20:441- 
6. Essman EJ, The medical uses of herbs , Fitoterpia , 1984; 55: 279-289.

7. Forbes BA, Shan DF, \& Weissfeld AS Bailey and Scotts diagnostic microbiology , 12 th edition Elsevier . 2007 .

8. Garau J , " B- lactamase : current situation and clinical importance ", Intensive Care Med. 1994;, 20(suppl.)3:55-59.

9. Hussein FT . Medicinal plants in Libya , Arabic Encyclopedia house , Tripoli-Libya , 1986 : $\mathrm{p}: 180$.

10. Jacab R , Isensee $H$, Riet ZB , \& Makdessi R , Cardio protection by dietary interventions in animal experiments. Effects of garlic and various dietary oils under the conditions of experimental infrarction, Pharm . Pharmacol. Lett. , , 1993 ; 3:124-127.

11. Jassim SJ , Effect of Haloxylon articulatum extract on some experimental bacterial and fungal skin infection in dogs. MSc. Thesis , Pharmacology and Toxicology Department / College of Veterinary Medicine, University of Baghdad, 2003 .

12. Krell R , Value-Added products from Bee keeping, Agricultural Services Belletin, 1996; No. 124.

13. Laenger R , Mechtler C , \& Jurenitsch J , Composition of the essential oils of commercial samples of Salvia officinalis $\mathrm{L}$. and $\mathrm{S}$. fruticase Miller : A comparison of oils obtained by extraction and steam distillation , Phytochemical Analysis , 1996; 7:289-293 .

14. Reuter HD . Koch HP , \& Lawson DL Therapeutic effects and applications of Garlic and its preparations in : Garlic: The Science and therapeutic actions of Allium sativum L. and realted species ", $2^{\text {nd }}$ Edn , Koch , H.P. and D.L. Lawson (Eds) : Wilkins, Baltamare , MD. , 1996; PP135213.

15. Saeed S , \& Tariq P, Anti-bacterial activities of Mentha piperita , Pisum sativum and Momordica charantia , 2005; Pak.J.Bot. , 37:997-213.

16. - Sasaki JT , Kita K , Ishita H , Uchisasawa H , \& Matuse H , Anti-bacterial activity of garlic powder against Escherichia coli 0157 , J. Nutr. Sci.Vitaminol. . 1999;45:785-790.

17. Setiawan VW, Yu GP, Lu QY, Yu SZ , Mu L. hang Z , Kutz RC, Cai L , Hsich CC, \& Zhang ZF , Allium vegetables and stomach cancer risk in china, Asian Pac. Cancer Prev. , 2005; 6 : 387-395.

18. Shadkchan Y, Shemesh E, Mirelman D , Miron T, Rabinkov A, Wilchek $\mathrm{M}, \&$ Oisherov $\mathrm{N}$, Efficacy of allicin, the reactive molecule of garlic, in inhibitory Aspergillus ssp. In vitro and in a murine model of disseminated aspergillasis , $J$. Antimicrob. Chemother., 2004; 53:832-836.

19. Sivam GP , protection against Helicabacter pylori and other bacterial infections by garlic,$J$. Natr. , , 2001 ; 131:1106-08.

20. Vilegs-Jande H, DeMarchi E , \& Lances FM , Extraction of low polarity compounds ( with emphasis on coumarin and kaurendic acid) from Mikania glomerata (guaca) leaves , Phytochemical Analysis, 1997; 8:266-270.

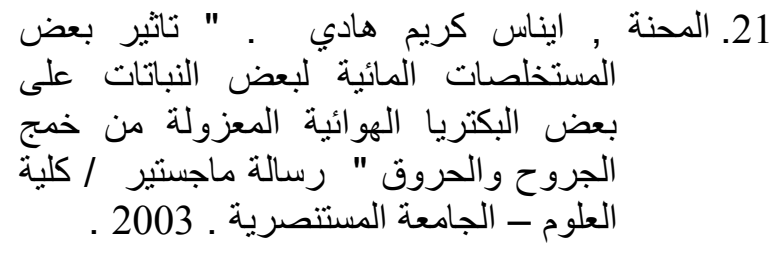




\section{" فعالية المستخلص الكحولي للثوم في نمو جرثومة المكورات العنقودية الذهبية

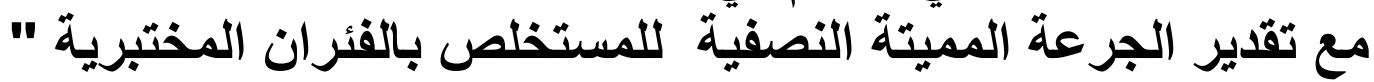 \\ شهباء مسلم الخزرجي \\ المعهد الطبي التقني/ منصور \\ هيئة التعليم التقني \\ شيماء جمال \\ كلية الطب , جامعة بغداد \\ عماد محمد رشيد \\ المعهد الطبي التقني/ منصور \\ هيئة التعليم التنقني}

الخلاصة

اجريت هذة الدراسة لمعرفة فعالية المستخلص الكحولي للثوم في تثبيط نمو جرثومة المكورات العنقودية ( خارج الجسم )

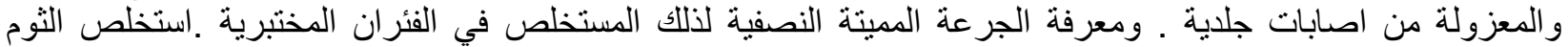
باستخدام الكحول الاثيلي 95\% وقد بلغت نسبة الاستخلاص 44\% من من وزن مسحوق المادة الجاف ـ وحضرت تراكيز

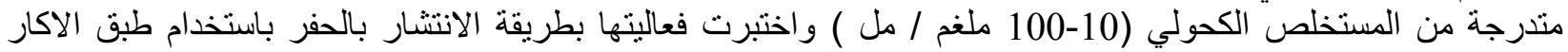

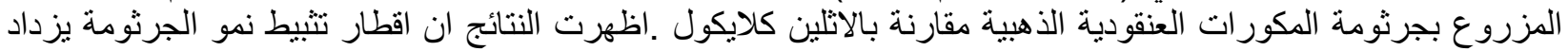

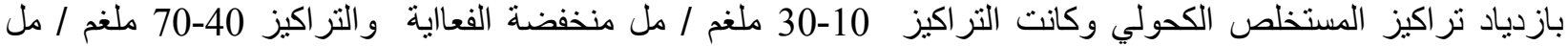

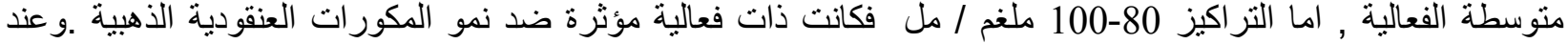

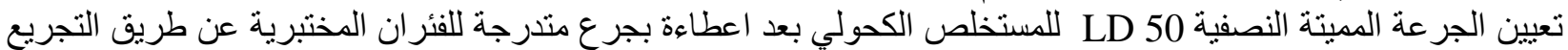

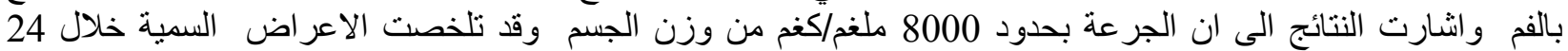

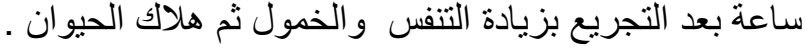

